Edubiotik: Jurnal Pendidikan, Biologi dan Terapan

ISSN 2528-679X (print), ISSN 2597-9833 (online)

Volume 4, Nomor 02, Tahun 2019, Hal. 93 - 100

Available online at:

http://ejurnal.budiutomomalang.ac.id/index.php/edubiotik

\title{
Peningkatan hasil belajar siswa sekolah dasar menggunakan media kertas bergambar pada materi perkembangbiakan tumbuhan tema 1
}

\author{
Enin Iriani
}

SD Negeri Jatimulya 02, Tambun Selatan, Bekasi, Indonesia

E-mail: eniniriani70@gmail.com

\begin{tabular}{|c|c|}
\hline Informasi Artikel & ABSTRACT \\
\hline $\begin{array}{l}\text { Submit: } \\
31-07-2019 \\
\text { Diterima: } \\
21-08-2019 \\
\text { Dipublikasikan: } \\
01-09-2019\end{array}$ & $\begin{array}{l}\text { Student learning outcomes on plant propagation material need to be } \\
\text { improved. That is because the material is difficult and needs media to help to } \\
\text { learn. The purpose of this research is to improve student learning outcomes at } \\
\text { primary school level using paper media display on plant propagation material. } \\
\text { The method used is Classroom Action Research with three cycles. The study } \\
\text { was conducted on July 2019. The instrument used was a matter of learning } \\
\text { achievement test in the form of a description item. The results showed that } \\
\text { student learning outcomes increased after using illustrated paper on plant } \\
\text { breeding material, even though the increase in learning outcomes was } \\
\text { included in the low category (N-gain < } 0.3 \text { ). The conclusion of this research is } \\
\text { an increase in student learning outcomes in plant breeding material using } \\
\text { pictorial paper media. } \\
\text { Key words: Illustrated paper, Learning media, Learning outcomes }\end{array}$ \\
\hline Penerbit & ABSTRAK \\
\hline $\begin{array}{l}\text { Program Studi } \\
\text { Pendidikan Biologi, } \\
\text { Fakultas Pendidikan } \\
\text { Ilmu Eksakta dan } \\
\text { Keolahragaan, IKIP } \\
\text { Budi Utomo, Malang, } \\
\text { Indonesia }\end{array}$ & $\begin{array}{l}\text { Hasil belajar siswa pada materi perkembangbiakan tumbuhan perlu } \\
\text { ditingkatkan. Hal tersebut dikarenakan materi tersebut sulit dan perlu media } \\
\text { membantu pembelajaran. Tujuan penelitian ini adalah untuk meningkatkan } \\
\text { hasil belajar siswa pada jenjang Sekolah Dasar menggunakan media kertas } \\
\text { bergambar pada materi perkembangbiakan tumbuhan. Metode yang } \\
\text { digunakan adalah Penelitian Tindakan Kelas dengan tiga siklus. Penelitian } \\
\text { dilaksanakan pada bulan Juli } 2019 \text {. Instrumen yang digunakan berupa soal } \\
\text { tes hasil belajar berbentuk soal uraian. Hasil penelitian menunjukan bahwa } \\
\text { hasil belajar siswa mengalami peningkatan setelah menggunakan kertas } \\
\text { bergambar pada materi perkembangan tumbuhan, walaupun peningkatan } \\
\text { hasil belajar tersebut termasuk dalam kategori rendah ( } \mathrm{N} \text {-gain }<0,3 \text { ). } \\
\text { Simpulan dari penelitian ini adalah terjadi penigkatan hasil belajar siswa pada } \\
\text { materi perkembangbiakan tumbuhan menggunkan media kertas bergambar. } \\
\text { Kata kunci: Hasil belajar, kertas bergambar, media pembelajaran }\end{array}$ \\
\hline
\end{tabular}

This Edubiotik : Jurnal Pendidikan, Biologi dan Terapan is licensed under a CC BY-SA (Creative Commons Attribution-ShareAlike 4.0 International License)

\section{PENDAHULUAN}

Pembelajaran Biologi di jenjang Sekolah Dasar (SD) yang tersaji pada buku tematik perlu ditingkatkan, terutama pada materi-materi yang sulit dipahami oleh siswa. Biasanya materi yang sulit memerlukan kemampuan siswa dalam menggambarkan objek yang sedang dipelajari, misalnya mengenai organ-organ tumbuhan. Siswa harus bisa menggambarkan bagian tumbuhan itu dengan tepat. Hal tersebut memerlukan pemahaman yang baik (Fitriani, Adisyahputra, \& Komala, 2018; Khan \& Masood, 2015). Lebih jauh lagi, siswa sekarang memerlukan 
kemampuan Higher Order Thinking Skills, namun hal tersebut bisa diraih apabila pemahaman konsep yang dasarnya sudah baik (Ichsan, Sigit, \& Miarsyah, 2019b).

Pada materi biologi yang membahas mengenai perkembangbiakan tumbuhan, siswa harus mampu menggambarkan bagian-bagian bunga. Selain itu, siswa juga harus bisa menggambarkan berbagai cara perkembangbiakan vegetatif pada tumbuhan. Materi ini sangat penting untuk dikuasai oleh siswa dikarenakan materi tersebut merupakan materi dasar yang harus dikuasai siswa pada jenjang Sekolah Dasar. Berdasarkan pengalaman mengajar selama ini, beberapa siswa sulit untuk memahami materi tersebut, sehingga menyebabkan hasil belajar siswa rendah (Supriyatin \& Ichsan, 2018; Yusuf, Amin, \& Nugrahaningsih, 2017).

Rendahnya hasil belajar siswa disebabkan karena kurangnya media pembelajaran yang digunakan pada materi tersebut. Oleh karena itu, perlu dilakukan upaya peningkatan hasil belajar biologi pada materi perkembangbiakan tanaman. Upaya yang akan dilakukan adalah dengan menerapkan media pembelajaran berupa kertas bergambar. Media ini merupakan sebuah media yang berisi gambar-gambar, misalnya saja gambar bunga, batang atau akar. Hal ini akan membantu siswa memahami materi (Ichsan, Hasanah, Aini, Ristanto, \& Miarsyah, 2019; Nugraini, Choo, Hin, \& Hoon, 2013; Yusuf et al., 2017). Penggunaan media kertas bergambar ini sudah banyak diteliti sebelumnya pada topik pembelajaran yang lain. Beberapa hasil penelitian menunjukkan bahwa, penggunaan media berbasis visual ini dapat meningkatkan kualitas pembelajaran (Aslan, 2015; Nugraini et al., 2013; Sever, Yurumezoglu, \& Oguz-Unver, 2010; Smith, 2014).

Melalui penggunaan media bergambar ini diharapkan dapat meningkatkan hasil belajar siswa pada materi perkembangbiakan tanaman. Hal perlu diketahui, salah satu karakteristik pembelajaran materi perkembangbiakan tanaman adalah memerlukan visualisasi berupa gambar. Media kertas bergambar ini dapat membantu siswa yang tinggal di perkotaan untuk mempelajari materi ini, karena mereka biasanya akan mengalami kesulitan dalam mencari contoh-contoh tanaman yang kontekstual untuk dipelajari (Bahtiar \& Dukomalamo, 2019; Kartikaningtyas, Kusmayadi, \& Riyadi, 2018). Berdasarkan hal yang telah diuraikan sebelumnya, maka tujuan dari penelitian ini adalah untuk meningkatkan hasil belajar siswa pada materi perkembangbiakan tumbuhan di jenjang SD.

\section{METODE PENELITIAN}

Jenis penelitian ini adalah Peneltian Tindakan Kelas dengan 3 siklus penelitian. Penelitian ini dilaksanakan pada bulan Juli 2019 di SD Negeri Jatimulya 02, Tambun Selatan, Bekasi. Sampel yang digunakan dalam penelitian ini adalah siswa kelas 6 dengan jumlah siswa sebanyak 36 siswa.

Media pembelajaran yang digunakan pada penelitian ini adalah berupa kertas bergambar yang berisi gambar bunga, batang, dan lainnya yang berkaitan dengan perkembangbiakan tanaman. Gambar-gambar pada media ini dibuat sendiri oleh siswa secara berkelompok. Satu kelompok siswa terdiri dari 4 orang siswa. Pada tahapan perencanaan, dibuat perencanaan pembelajaran serta menyiapkan instrumen dan media yang diperlukan pada saat pembelajaran. Setelah itu, dilakukan pelaksanaan dengan melakukan proses pembelajaran berbantuan media kertas 
bergambar. Salah satu kegiatan yang dilakukan siswa selama kegiatan pembelajaran, siswa membuat gambar secara berkelompok. Selama pelaksanaan pembelajaran dilakukan pula kegiatan pengamatan. Setelah itu, dilakukan evaluasi. Instrumen yang digunakan pada penelitian ini adalah tes hasil belajar kognitif. Soal tes berupa soal uraian. Tahap akhir dari satu siklus penelitian adalah refleksi. Adapun untuk mengetahui besar peningkatan digunakan rumus gain skor ( $N$-gain), dengan rumus sebagai berikut.

$$
\mathrm{N} \text {-gain }=\frac{\text { Rerata Skor Siklus 2-Rerata Skor siklus } 1}{100-\text { Rerata skor siklus } 1}
$$

Setelah gain skor selesai dihitung, maka dilanjutkan dengan mengkategorikan gain skor tersebut. Gain skor ( $N$-gain) terdiri dari kategori tinggi, sedang, dan rendah. Kriteria Gain Skor sebagaimana tersaji pada Tabel 1.

Tabel 1. Kriteria Gain Skor (N-gain)

\begin{tabular}{cc}
\hline Gain Skor $(\boldsymbol{N}$-gain $)$ & Kriteria \\
\hline $\mathrm{g} \geq 0,7$ & Tinggi \\
$0,7>\mathrm{g} \geq 0,3$ & Sedang \\
$\mathrm{g}<0,3$ & Rendah \\
\hline
\end{tabular}

\section{HASIL PENELITIAN DAN PEMBAHASAN}

Hasil penelitian menunjukkan bahwa media pembelajaran berupa kertas bergambar dapat meningkatkan hasil belajar Biologi siswa kelas 6 SD Negeri Jatimulya 02, Tambun Selatan, Bekasi. Hal ini diketahui dari rata-rata skor hasil belajar siswa, dimana rata-rata skor hasil belajar siswa paling tinggi adalah pada siklus 3. Informasi mengenai rata-rata skor hasil belajar siswa pada masing-masing siklus sebagaimana tersaji pada Tabel 2.

Tabel 2. Rata- rata Skor Hasil Belajar Siswa Tiap Siklus

\begin{tabular}{ccc}
\hline & Tahap & Rata-rata Skor \\
\hline Siklus 1 & 63.22 \\
Siklus 2 & 66.67 \\
Siklus 3 & 70.00 \\
\hline
\end{tabular}

Berdasarkan data yang disajikan pada Tabel 2 dapat diketahui bahwa peningkatan rata-rata skor hasil belajar siswa untuk masing-masing siklus tidak terlalu tinggi. Agar memperjelas informasi mengenai kenaikan rata-rata skor hasil belajar masing-masing siklus disajikan Gambar 1.

Selain dihitung skor rata-rata hasil belajar siswa, dihitung pula gain skor dan dikategorikan pula gain skor hasil penghitungan. Pengkategorian gain skor berdasarkan pada Tabel 1. Jika dilihat dari kategori gain skor, peningkatannya masuk dalam ketegori rendah. Data gain skor ( $N$-gain) sebagaimana tersaji pada Tabel 3. 




Gambar 1. Grafik Rata-rata Skor Hasil Belajar

Tabel 3. Hasil Interpretasi Gain Skor (N-gain) Setiap Siklus

\begin{tabular}{ccc}
\hline Tahapan & Gain skor $(\mathbf{N}$-gain $)$ & Kriteria \\
\hline Siklus 1-2 & 0,09 & Rendah \\
Siklus 2-3 & 0,10 & Rendah \\
Siklus 1-3 & 0,18 & Rendah \\
\hline
\end{tabular}

Sebagaimana yang telah disampaikan sebelumnya, hasil penelitian menunjukan bahwa hasil belajar siswa SD Negeri Jatimulya 02, Tambun Selatan Bekasi pada materi perkembangbiakan tumbuhan meningkat, tetapi peningkatan hasil belajar tersebut tidak terlalu tinggi. Peningkatan hasil belajar ini disebabkan karena penggunaan media kertas bergambar dapat memudahkan siswa dalam memahami konsep. Selain itu, kegiatan pembelajaran yang dilakukan secara berkelompok atau diskusi akan melatih siswa untuk bisa bekerjasama diantara mereka. Kemampuan ini sangat diperlukan dalam pembelajaran abad 21 (Aslan, 2015; Boholano, 2017; Ichsan, Sigit, \& Miarsyah, 2019a; Kuhlthau, 2010; Quieng, Lim, \& Lucas, 2015).

Berdasarkan hasil refleksi yang telah dilakukan, diperoleh saran agar kertas gambar yang digunakan sebagai media lebih besar, misalnya saja berukuran A3. Hal tersebut agar siswa bisa menggambar lebih banyak di kertas tersebut. Saran lainnya adalah peralatan gambar yang digunakan sebaiknya tidak hanya pensil, melainkan dilengkapi pula dengan pensil warna dan krayon. Hal itu supaya gambar yang dihasilkan siswa tidak hanya berwarna hitam putih melainkan memiliki warna yang lebih menarik. Hal tersebut berdampak kepada pembelajaran yang lebih aktif (Camacho \& Legare, 2015; Ichsan, Dewi, Hermawati, \& Iriani, 2018; Ichsan \& Mulyani, 2018; Stover \& Ziswiler, 2017). Gambar 2 dan Gambar 3 merupakan kegiatan yang dilakukan siswa pada penelitian ini.

Saran lain yang diperoleh dari proses refleksi ini adalah belum adanya interaksi antar kelompok. Seharusnya kegiatan ini difasilitasi oleh guru selama pembelajaran di kelas. Kelompok yang telah menyelesaikan tugas menggambarnya dapat diarahkan oleh guru untuk melakukan persentasi di depan kelas. Kegiatan ini dapat meningkatkan kemampuan komunikasi siswa (Hemmerich, Hoepner, \& Samelson, 2015; Kivunja, 2014; Mercer-Mapstone \& Kuchel, 2017; Wolfson \& Funke, 2014). 


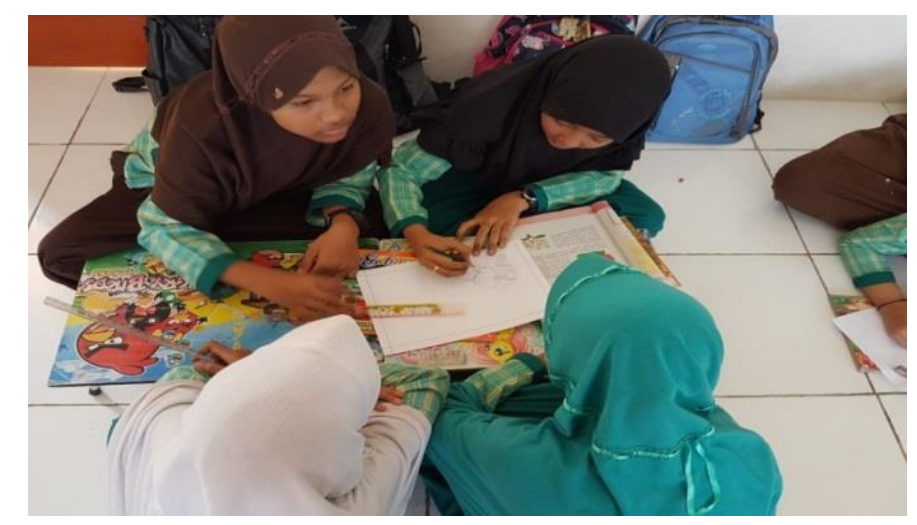

Gambar 2. Kegiatan Siswa Perempuan Dalam Membuat Kertas Bergambar (Sumber: Dokumentasi Pribadi, 2019)

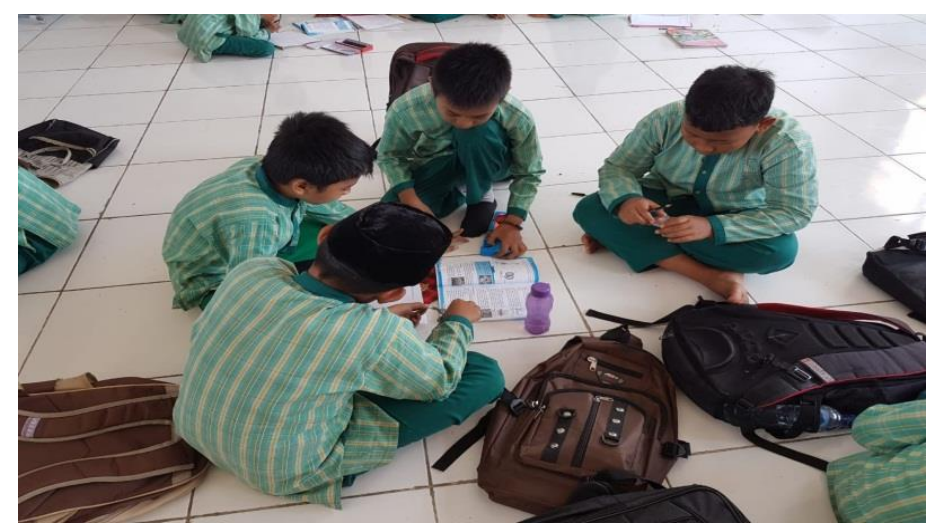

Gambar 2. Kegiatan Siswa Laki-laki Dalam Membuat Kertas Bergambar (Sumber: Dokumentasi Pribadi, 2019)

Pada pembelajaran di jenjang SD juga dapat dilakukan dengan media lain seperti poster dan carta. Hal tersebut dikarenakan siswa SD dapat lebih mudah memahami sebuah materi melalui gambar. Siswa yang ada di jenjang SD harus dapat memahami materi Biologi dengan baik, karena materi ini merupakan materi dasar yang harus dikuasai oleh siswa dengan baik (Hacieminoglu, 2016; Ichsan, Sigit, Miarsyah, Azrai, \& Heryanti, 2019; Koc \& Yager, 2016; Leong, Mohd Said, Shahrill, \& Perera, 2016). Jika siswa SD tidak menguasai materi ini dengan baik, maka kemungkinann besar akan mengalami kesulitan dalam memahami materi Biologi di jenjang berikutnya yaitu di jenjang SMP.

\section{SIMPULAN DAN SARAN}

Berdasarkan hasil penelitian yang telah dilakukan, dapat disimpulkan bahwa media pembelajaran berupa kertas bergambar dapat meningkatkan hasil belajar siswa pada materi perkembangbiakan tumbuhan di SD Negeri Jatimulya 02, Tambun Selatan, Bekasi. Peningkatan hasil belajar tersebut masih tergolong rendah $(\mathrm{N}$-gain $<$ 3). Meskipun demikian, peningkatan tersebut masih tergolong baik karena materi perkembangbiakan tumbuhan adalah salah satu materi yang sulit untuk dipelajari oleh siswa SD. Berdasarkan penelitian ini, maka disarankan untuk mengembangkan berbagai media pembelajaran yang lebih menarik bagi siswa agar pembelajaran semakin baik di jenjang Sekolah Dasar. 


\section{UCAPAN TERIMA KASIH}

Terima kasih kepada seluruh pihak yang telah membantu dalam Penelitian Tindakan kelas ini. Tanpa bantuan dari segala pihak, tidak akan berjalan dengan lancar kegiatan penelitian ini. Semoga hasil penelitian tindakan kelas ini bermanfaat.

\section{RUJUKAN}

Aslan, S. (2015). Is learning by teaching effective in gaining 21st century skills? The views of pre-service science teachers. Kuram ve Uygulamada Egitim Bilimleri, 15(6), 1441-1457. https://doi.org/10.12738/estp.2016.1.0019

Bahtiar, B., \& Dukomalamo, N. (2019). Basic science process skills of biology laboratory practice: improving through discovery learning. Biosfer: Jurnal Pendidikan Biologi, 12(1), 83-93. https://doi.org/10.21009/biosferjpb.v12n1.8393

Boholano, H. B. (2017). Smart Social Networking: 21st Century Teaching And Learning Skills. Research in Pedagogy, 7(1), 21-29. https://doi.org/10.17810/ $\% 202015.45$

Camacho, D. J., \& Legare, J. M. (2015). Opportunities to Create Active Learning Techniques in the Classroom. Journal of Instructional Research, 4, 38-45. Retrieved from https://files.eric.ed.gov/fulltext/EJ1127696.pdf

Fitriani, U., Adisyahputra, A., \& Komala, R. (2018). Eco-friendly website development in biology learning based on project activities on environmental pollution. Biosfer: Jurnal Pendidikan Biologi, 11(1), 32-46. https://doi.org/10.21009/biosferjpb.111.4

Hacieminoglu, E. (2016). Elementary school students' attitude toward science and related variables. International Journal of Environmental and Science Education, 11(2), 35-52. https://doi.org/10.12973/ijese.2016.288a

Hemmerich, A. L., Hoepner, J. K., \& Samelson, V. M. (2015). Instructional Internships: Improving the teaching and learning experience for students, interns, and faculty. Journal of the Scholarship of Teaching and Learning, 15(3), 104. https://doi.org/10.14434/josotl.v15i3.13090

Ichsan, I. Z., Dewi, A. K., Hermawati, F. M., \& Iriani, E. (2018). Pembelajaran IPA dan Lingkungan: Analisis Kebutuhan Media Pembelajaran pada SD, SMP, SMA di Tambun Selatan, Bekasi. JIPVA (Jurnal Pendidikan IPA Veteran), 2(2), 131140. https://doi.org/10.31331/jipva.v2i2.682

Ichsan, I. Z., Hasanah, R., Aini, S., Ristanto, R. H., \& Miarsyah, M. (2019). Higher Order Thinking Skills Assessment based on Environmental Problem (HOTSAEP): Mendesain Evaluasi Pembelajaran Abad 21. Jurnal Biotek, 7(1), 14-26. Retrieved from http://journal.uin-alauddin.ac.id/index.php/biotek/article/view/ 7939

Ichsan, I. Z., \& Mulyani, S. W. W. (2018). Improving Students' Motoric Skills Through Demonstration Method in Recycling Plastic Waste. JPBI (Jurnal Pendidikan Biologi Indonesia), 4(2), 189-194. https://doi.org/10.22219/jpbi.v4i2.5890

Ichsan, I. Z., Sigit, D. V., \& Miarsyah, M. (2019a). Environmental Learning Based on Higher Order Thinking Skills: A Needs Assessment. International Journal for Educational and Vocational Studies, 1(1), 21-24. https://doi.org/10.29103/ ijevs.v1i1.1389

Ichsan, I. Z., Sigit, D. V., \& Miarsyah, M. (2019b). Students Higher Order Thinking Skills: Analyze, Evaluate, Create Green Consumerism Solution in Environmental Learning. International Journal for Educational and Vocational 
Studies, 1(4). Retrieved from https://ojs.unimal.ac.id/index.php/ijevs/article/view/ 1434

Ichsan, I. Z., Sigit, D. V., Miarsyah, M., Azrai, E. P., \& Heryanti, E. (2019). Students' pro-environmental behavior and environmental learning outcomes based on green consumerism. Jurnal Pendidikan Biologi Indonesia, 5(1), 109-116. https://doi.org/10.22219/jpbi.v5i1.6447

Kartikaningtyas, V., Kusmayadi, T. A., \& Riyadi, R. (2018). The effect of brain based learning with contextual approach viewed from adversity quotient. Journal of Physics: Conference Series, 1022. Retrieved from http://iopscience.iop. org/article/10.1088/1742-6596/1022/1/012014

Khan, F. M. A., \& Masood, M. (2015). The Effectiveness of an Interactive Multimedia Courseware with Cooperative Mastery Approach in Enhancing Higher Order Thinking Skills in Learning Cellular Respiration. Procedia - Social and Behavioral Sciences, 176, 977-984. https://doi.org/10.1016/j.sbspro.2015.01.567

Kivunja, C. (2014). Teaching Students to Learn and to Work Well with 21 st Century Skills: Unpacking the Career and Life Skills Domain of the New Learning Paradigm. International Journal of Higher Education, 4(1), 1-11. https://doi.org/10.5430/ijhe.v4n1p1

Koc, I., \& Yager, R. E. (2016). Preservice teachers' alternative conceptions in elementary science concepts. Cypriot Journal of Educational Sciences, 11(3), 144-159. Retrieved from http://sproc.org/ojs/index.php/cjes/

Kuhlthau, C. C. (2010). Guided inquiry: School libraries in the 21st century. School Libraries Worldwide, 16(1), 17-28. Retrieved from http://wp.comminfo.rutgers. edu/ckuhlthau/wp-content/uploads/sites/185/2016/02/Gl-School-Librarians-inthe-21-Century.pdf

Leong, S. S. M., Mohd Said, H., Shahrill, M., \& Perera, J. S. H. Q. (2016). Using lesson study to enhance meaningful understanding on the topic of pressure. International Journal of Environmental and Science Education, 11(15), 84258435. Retrieved from https://files.eric.ed.gov/fulltext/EJ1118023.pdf

Mercer-Mapstone, L., \& Kuchel, L. (2017). Core Skills for Effective Science Communication: A Teaching Resource for Undergraduate Science Education. International Journal of Science Education, Part B: Communication and Public Engagement, 7(2), 181-201. https://doi.org/10.1080/21548455.2015.1113573

Nugraini, S. H., Choo, K. A., Hin, H. S., \& Hoon, T. S. (2013). Students' Feedback of e-AV Biology Website and the Learning Impact towards Biology. Procedia Social and Behavioral Sciences, 103, 860-869. https://doi.org/10.1016/j.sbspro. 2013.10.408

Quieng, M. C., Lim, P. P., \& Lucas, M. R. D. (2015). 21st Century-based Soft Skills: Spotlight on Non-cognitive Skills in a Cognitive-laden Dentistry Program. European Journal of Contemporary Education, 11(1), 72-81. https://doi.org/10.13187/ejced.2015.11.72

Sever, S., Yurumezoglu, K., \& Oguz-Unver, A. (2010). Comparison teaching strategies of videotaped and demonstration experiments in inquiry-based science education. Procedia - Social and Behavioral Sciences, 2(2), 5619-5624. https://doi.org/10.1016/j.sbspro.2010.03.916

Smith, T. (2014). Elementary Science Instruction: Examining a Virtual Environment for Evidence of Learning, Engagement, and 21st Century Competencies. Education Sciences, 4(1), 122-138. https://doi.org/10.3390/educsci4010122

Stover, S., \& Ziswiler, K. (2017). Impact of Active Learning Environments on Community of Inquiry. International Journal of Teaching and Learning in Higher Education, 29(3), 458-470. Retrieved from http://ezproxy.lib.uconn.edu/login?ur 
I=https://search.ebscohost.com/login.aspx?direct=true\&db=eric\&AN=EJ115076 $0 \&$ site $=$ ehost-live

Supriyatin, S., \& Ichsan, I. Z. (2018). Pengayaan Materi Pertumbuhan dan Perkembangan Tumbuhan Melalui Pengembangan Bahan Ajar. Jurnal Biotek, 6(2), 13-24. https://doi.org/https://doi.org/10.24252/jb.v6i2.6468

Wolfson, T., \& Funke, P. N. (2014). Communication, class and concentric media practices: Developing a contemporary rubric1. New Media and Society, 16(3), 363-380. https://doi.org/10.1177/1461444813481199

Yusuf, M. M., Amin, M., \& Nugrahaningsih. (2017). Developing of Instructional MediaBased Animation Video on Enzyme and Metabolism Material. Jurnal Pendidikan Biologi Indonesia, 3(3), 254-257. Retrieved from http://ejournal.umm.ac.id/index .php/jpbi/article/view/4744 